\title{
Paisagens moventes: territórios íntimos de Tadeu Lobato
}

\author{
Alberto Amaral
}

In memória de Nice Villas Boas, minha avó querida.

Todo abismo é navegável a barquinho de papel.

Guimarães Rosa

\section{$\mathrm{O}$}

presente ensaio nos apresenta algumas questões presentes na série de pinturas intitulada Paisagem moventes que o artista plástico paraense Tadeu Lobato expõe no Atelier do Porto, em Belém do Pará, sob curadoria de Alberto Amaral, após alguns anos sem apresentar seu trabalho ao público em geral. Percebemos neste trabalho que o artista apresenta em suas pinturas suas memórias e referências que permeiam em todo o seu trabalho.

Em uma abertura que se abre para o inconsciente e desvela no silêncio para o Real, Paisagem moventes do artista paraense Tadeu Lobato, nos lança para um desconhecido, que não é um objeto ainda não conhecido, quer dizer, sabemos de sua existência, estamos diante dele, porém jamais chegaremos a conhecê-lo realmente de forma a lhe atribuir qualquer sentido, visto que seu lugar é estranho à nossa "visibilidade". Talvez a proposta de Tadeu Lobato seja mais uma atitude de crer (uma crença) que o ser está aí, "há" um ser, e eu acredito nisso, porém não posso alcançá-lo. Estamos diante da incapacidade de compreensão, de interpretação, de conferir a ele uma identidade. A possibilidade é uma espécie de 
guardiã do ser que pretende preservá-lo dessa outra experiência, que é sempre mais primordial do que a possibilidade que nomeia o ser. A impossibilidade não é nem afirmação nem negação, é o que "desde sempre precedeu o ser", e não se entrega a nenhuma ontologia (BLANCHOT, 2001, p. 92).

Puxando a paisagem para dentro do inconsciente, seu trabalho questiona, nos faz refletir sobre nossas memórias arquivadas, sem dúvida, os limites desta reminiscência e do seu próprio campo de visibilidade da arte. Seus fios, dialogando com a bela paisagem do luar, levam-nos de dentro para fora da natureza e para dentro da memória reservada à contemplação da arte para a natureza e para a vida, e para a arte. Podemos ver, nas imagens que acompanham esse ensaio, o jogo Fora-dentro que esse trabalho realiza, valendo-se da transparência da paisagem em diálogo com a memória.

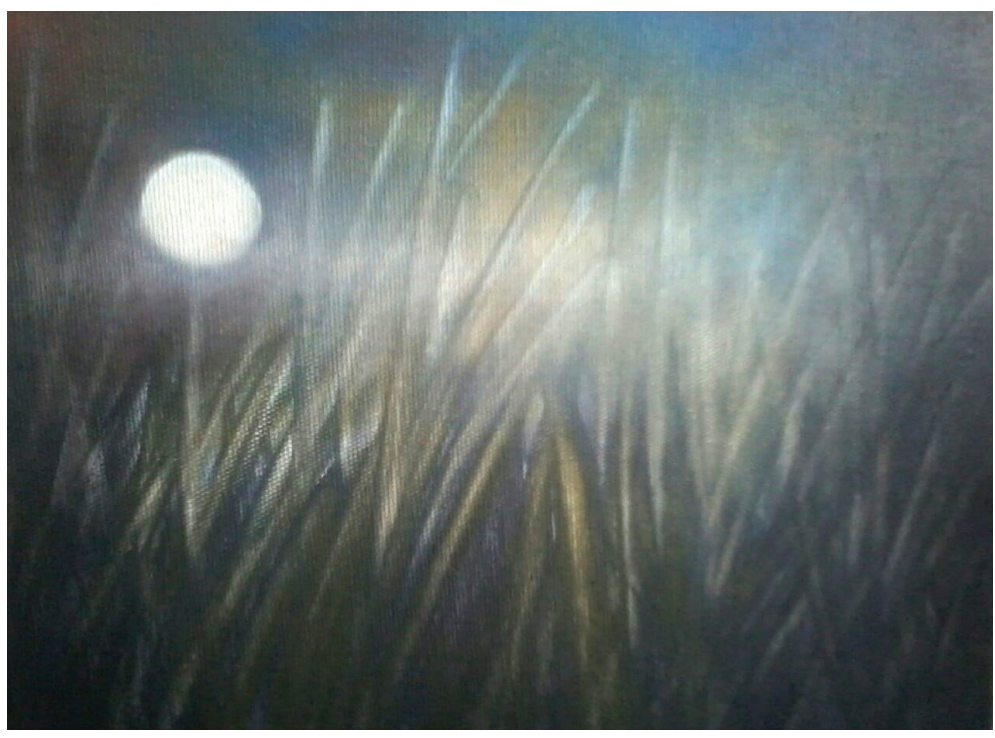

Tadeu Lobato, sem título, óleo sobre tela. Fotografia de Alberto Amaral. 
A experiência é única pelo que a precede e pelo que a segue. Esse tempo, que chamaria de estrutural, nada mais é do que o tempo da narrativa, que Ricoeur chama de "fictício". Nas pinturas de Lobato, a experiência temporal aparece tanto como supressão do tempo cronológico, em que ele não sabe mais se o vento que sopra é da Belém da sua infância ou do Pacífico da emigrada, quanto uma radical disjunção. Há uma cerca de arame farpado entre a criança e os adultos. $O$ tempo é também o da relação impossível entre dois eventos, duas situações, dois tempos. É como se a vida e a morte não tivessem nada a ver uma com a outra: experiências inconciliáveis. A atemporalidade e, ao mesmo tempo, a disjunção entre passado e presente barram a possibilidade de identidade e de totalização.

Lacan, com sua necessária crítica à primazia do imaginário na psicanálise, segue um eixo fundamental à arte e à literatura de seu tempo, enunciado pelo grande Stéphane Mallarmé já em 1885: “o moderno desdenha imaginar” (MALLARMÉ, 1998). Além de desdenhar, o homem do século XX desconfiava das imagens e buscava modos de assegurar a elas alguma autenticidade quanto ao mundo e ao próprio homem. Essa pontuação histórica é importante para situar o pensamento psicanalítico acerca da imagem, mas ela não nos deve restringir a uma cronologia estéril. $\mathrm{O}$ importante não é tomar o moderno e o contemporâneo como momentos bem delimitados em relação ao que os precedeu. Como mostra o próprio Lacan, logo após a sistematização, no Renascimento, das regras da perspectiva que davam ao eu uma posição central e organizadora no mundo da representação, os pintores logo começam a subvertêlas, com a técnica da anamorfose (LACAN, 1998), de modo a apontar para algo que é furo na imagem - e golpeia fortemente a ilusória centralidade do eu. "O eu não é senhor em sua própria 
casa", como dizia Freud (1917/1944, p. 295), e a arte é o campo cultural que põe em jogo e à mostra seu descentramento, como podemos observar na imagem a seguir.

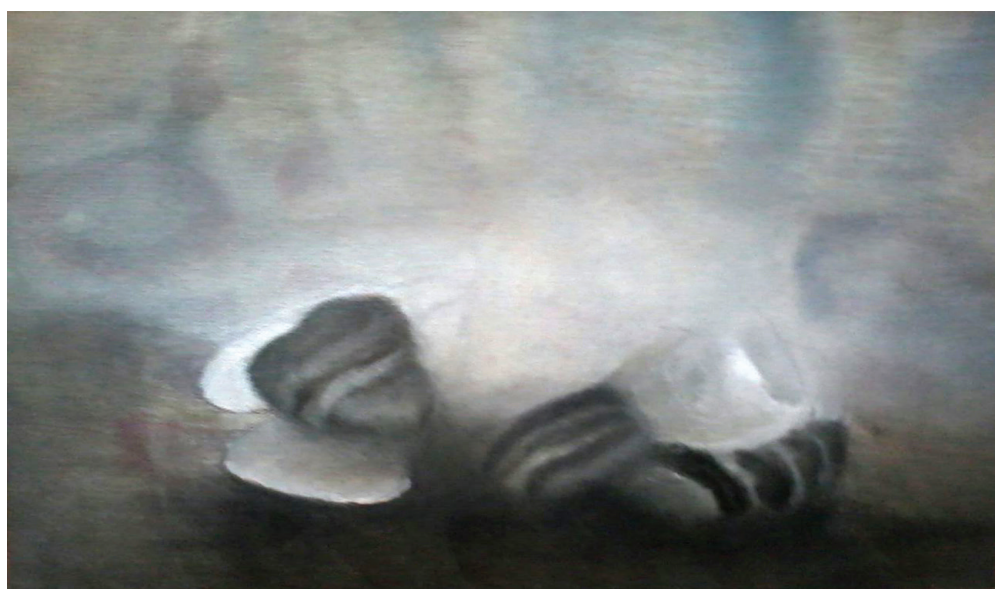

Tadeu Lobato, sem título, óleo sobre tela. Fotografia de Alberto Amaral.

Tadeu Lobato através de suas pinturas nos faz pensar o nosso tempo - o contemporâneo -, o importante não é nele apontar características próprias e inéditas, mas sim nele perceber repetições que se assumem como tal, apostando no só-depois como instante de furo e surgimento de algo imprevisto (como a psicanálise nos permite pensar com a noção freudiana de Nachtraglichkeit). Não teremos espaço, nessa breve nota, de aprofundar e pôr à prova essa hipótese, mas é ela que fornece aqui o elã para uma reflexão sobre a arte, o existir da paisagem de Tadeu Lobato com o agora da memória do artista. 


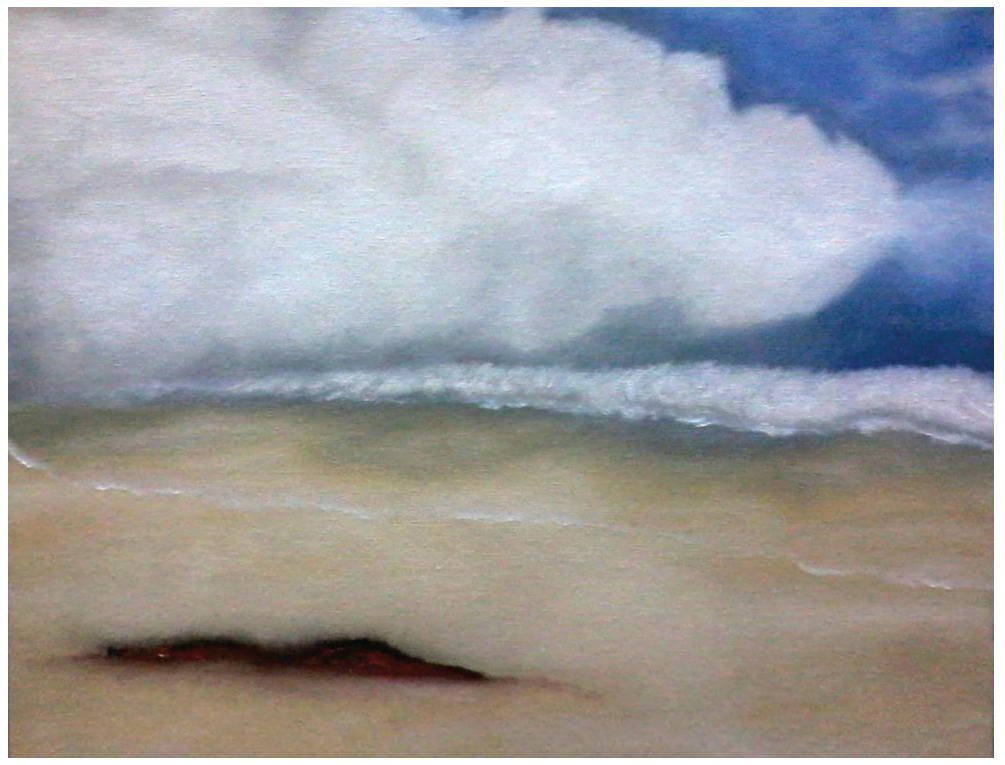

Tadeu Lobato, óleo sobre papel. Fotografia de Alberto Amaral.

Em sua Paisagem a Paria do Farol, Tadeu Lobato nos lança em seu Labirinto memorialístico, nos apresenta "A praia dos caramujos", formando um labirinto que se abre, a partir de sua imagem, um parêntese sobre essa imensa paisagem em eterno movimento que é por si só uma paisagem errante. A fala poética, fala que volta à exigência originária de um movimento, opondo-se a toda estabilidade, todo repouso. A praia é uma paisagem em suspensão, errante, é uma possível metáfora do dentro que está fora, afinal proporciona as tão temidas e desejadas miragens, que enganam os desejos, os sentidos. É um espaço vagamente delimitado inserido na paisagem, que por sua vez sugere miragens, outros espaços vagamente delimitados. Se virmos a praia como infinito, estamos presos a sua infinitude, presos no labirinto das miragens, sem saída, em desorientação, no entanto se o virmos como finito, saberemos 
que em algum momento encontraremos a saída, e ele se tornará então nossa orientação finita. Não devemos esquecer também que as paisagens trazem suas cumplicidades com as imagens e seres que as habitam, cumplicidades no sentido de conexão para que seja possível o desenvolver de uma existência.

Blanchot, ao escrever sobre a sabedoria da visão, mostra que toda visão é visão de conjunto, mantendo-nos nos limites de um horizonte aparentemente sem limite, pacto seguro de onde advém a paz. Já a palavra, é, para o olhar, guerra e loucura. A terrivel palavra ultrapassa todo limite, e, até, o ilimitado do todo: ela toma a coisa por onde não se a toma, por onde não é vista, nem nunca será vista; ela transgride as leis, liberta-se da orientação, ela desorienta. (BLANCHOT, 1998, p. 66).

Sobre a imagem e sobre a palavra, tratando da experiência literária apresentada por Blanchot e, de forma análoga, da experiência de formação de imagens dentro das artes plásticas, percorro a possibilidade de duas paisagens propostas, semelhante à relação criada pelo próprio escritor, a partir de Mallarmé, sobre as duas linguagens, uma sendo a linguagem bruta, do dia a dia, direcionada à comunicação, e outra, a essencial, que seria a poética e literária. Dessa maneira, proponho duas prováveis paisagens, uma palpável, fruto de uma natureza contemplada, revelando a sua importância do ponto de vista histórico, e outra poética, existente primordialmente na pintura e no desenho, no imaginário e na imagem em si.

Um porto imaginado e a paisagem vivida estão em intersecção, e neste interstício, entre a vigília e o sono, é onde se cultivam as sensações, matéria-prima para as linguagens, segundo o próprio escritor. Vivenciar a obra de arte e o processo criativo como se eles viessem antes de sua percepção, perceber o mundo a partir 
da poesia é mais uma vez o ponto de vista abordado, afinal, para vermos uma paisagem como poesia, temos que esquecê-la como paisagem e vê-la a partir do sonho, como uma imagem poética em si. Explicita-se dessa forma, dentro do âmbito blanchotiano, a criação como sonho das impossibilidades possíveis. Fernando Pessoa escrevia sobre a possibilidade infinita da escrita, onde a obra fazia-se, como diz Blanchot citando Mallarmé: como um livro feito, sendo.

O exterior, o fora é a distância entre as forças. A diferença entre essas forças constitui o espaço entre, como é o espaço entre os elementos da paisagem que a formam. Esse fora, chamado por Blanchot não de espaço, mas de vertigem do espaçamento, supõe a vertigem em relação ao abismo, como esse espaço entre. A praia circunda e constitui a palavra que a escrita blanchotiana configura. Local de erro onde os escritores se situam, instante de fascinação, zona de indeterminação sem começo, meio e fim, onde o pensamento ainda não começou a pensar: a praia; nas palavras de Blanchot, ainda não é nem o tempo, nem o espaço, mas um espaço sem lugar e um tempo sem engendramento. No centro dessa paisagem criada por Tadeu Lobato estamos enfim nesse espaço literário lobatiano, um espaço que o próprio artista entra em diálogos com Turner, Eliot, Celan, espaço, esse espaço é o fora, onde não se representa, mas se nega o real construindo uma irrealidade fictícia. Do mesmo modo que esses poetas evocados anteriormente faziam. Não nesse espaço, mas esse espaço onde tudo se torna imagem, aqui sim como uma outra versão, que não vem depois da coisa, afinal o objeto é a coisa e sua imagem ao mesmo tempo, só foi possível e necessário, logicamente, devido à arte, após esse processo lento e contínuo que se estende nas imagens e nas palavras, na música, na melodia dançando com a letra, nessa paisagem imanente que habita o mundo, chamada de obra. 
É no interior da obra que se encontra o fora absoluto exterioridade radical à prova da qual a obra se forma, como se o que está mais fora dela, fosse sempre, para aquele que escreve, seu ponto mais íntimo, de modo que ele precisa por um movimento muito arriscado, ir incessantemente até o extremo limite do espaço, manter-se como que no fim de si mesmo, no fim do gênero que ele acredita seguir, da história que acredita contar, e de toda escrita, ali onde não pode mais continuar: é ali que ele deve ficar, sem ceder, para que ali, em certo momento, tudo comece (BLANCHOT, 1998, p. 123).

Dentro desse ambiente nevoado blanchotiano, com a visão atrelada à pintura, abordada também como esse espaço intersticial do sonhado e do vivido, percebemos que a paisagem pode ser também uma forma de ver. Através da pintura, dentro desse ponto íntimo da experiência pictórica, trazendo o texto de Merleau-Ponty, $A$ dúvida de Cézanne, percebo pontos em comum com o pensamento de Blanchot sobre a obra; o que chamamos de A obra de Cézanne não era para ele, senão, o ensaio e aproximação de sua pintura, sendo esta seu mundo e sua maneira de existir, ou também que o pintor pensa por meio da pintura.

As paisagens moventes de Tadeu Lobato, são espaços férteis que fingem eternizar um instante enganosamente congelado. Espaços onde reside a composição, mesmo que esta seja apenas a escolha de uma primeira letra, mesmo que esta seja uma outra espécie de composição. E assim insere-se o ponto de vista que é responsável pela escolha, ou pelas escolhas que se estendem ao longo de um processo infinito, que nunca se encerra em um só trabalho de arte, em um só livro. Eis um fragmento de Maurice Blanchot que aponta para a questão da determinação ou indeterminação na literatura: 
Mas, precisamente, a essência da literatura escapa a toda a determinação essencial, a toda afirmação que a estabilize ou mesmo que a realize: nunca já lá está, está sempre por encontrar ou por reinventar. Nem sequer é certo que a palavra literatura ou a palavra arte alguma vez corresponda a algo de real, a algo de possível ou a algo de importante. Já foi dito: ser artista é nunca saber que já há uma arte, ou que já há um mundo. Certamente, o pintor vai ao museu e adquire, desse modo, uma certa consciência da realidade da pintura: ele sabe a pintura, mas o seu quadro não a sabe, o que este sabe é que a pintura é impossível, irreal, irrealizável. Quem afirma a literatura em si não afirma nada. Quem a busca, só busca o que se lhe furta; quem a encontra, só encontra o que está aquém ou, pior ainda, além da literatura. Por isso, afinal, o que cada livro persegue como se fosse a essência do que ama e desejaria apaixonadamente descobrir, é a não-literatura. (...) Pois nunca uma obra de arte pode dar-se por objecto de interrogação que a sustenta. Nunca um quadro poderia sequer começar, se se propusesse tornar visível a pintura (BLANCHOT, 2005, p. 51-52).

A arte nos leva a conceber desta forma, em oposição ao laço social da massa, a possibilidade de haver um laço reminiscência. Talvez possamos dizer que ele corresponde, simplesmente, à própria ideia de transmissão, no sentido forte que a psicanálise lacaniana dá a esse termo. Nesse sentido, é importante sublinhar que é o próprio sujeito que se produz, na transmissão, fora de si - já que seu íntimo está fora, é êxtimo. 


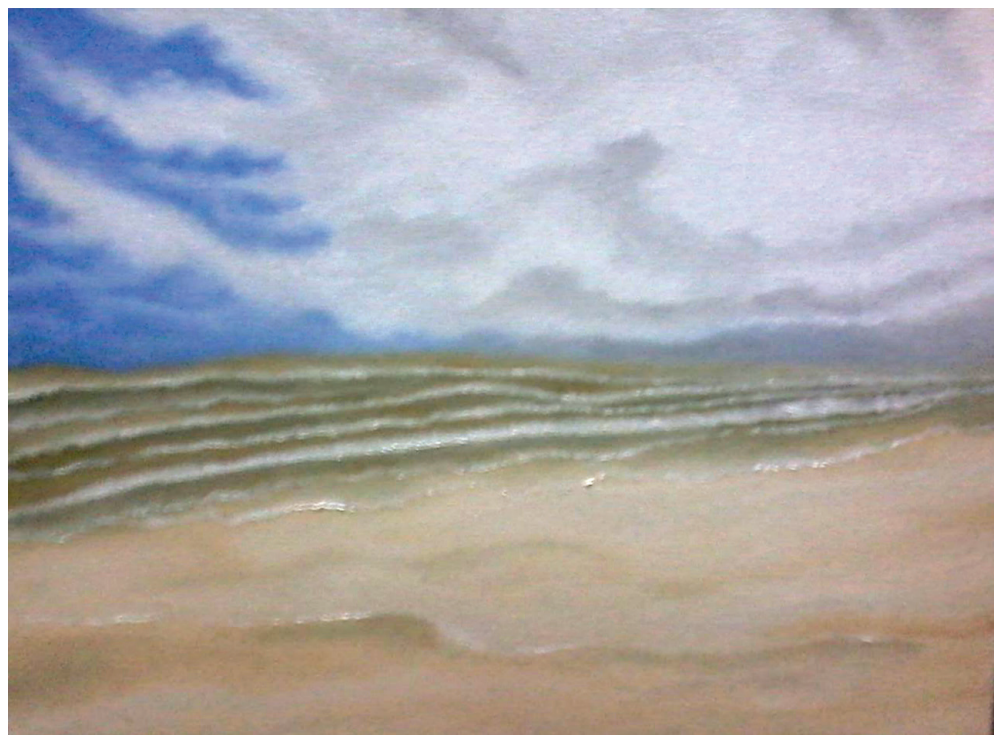

Tadeu Lobato, óleo sobre papel. Fotografia de Alberto Amaral.

Na imagem citada acima, Tadeu Lobato nos apresenta a partir de sua pintura, uma bela imagem, um parêntese sobre essa imensa paisagem em eterno movimento que é por si só uma paisagem errante. A fala poética, para Blanchot, é uma fala que volta à exigência originária de um movimento, opondo-se a toda estabilidade, todo repouso. O deserto é uma paisagem em suspensão, errante, é uma possível metáfora do dentro que está fora, afinal proporciona as tão temidas e desejadas miragens, que enganam os desejos, os sentidos. É um espaço vagamente delimitado, inserido na paisagem, que por sua vez sugere miragens, outros espaços vagamente delimitados. Se virmos o deserto como infinito, estamos presos a sua infinitude, presos no labirinto das miragens, sem saída, em desorientação, no entanto se o virmos como finito, saberemos que em algum momento encontraremos a saída, e ele 
se tornará então nossa orientação finita. Não devemos esquecer também que as paisagens trazem suas cumplicidades com as imagens e seres que as habitam, cumplicidades no sentido de conexão para que seja possível o desenvolver de uma existência de tempos variados, logo, um deserto que vejo não é o mesmo visto pelo tuaregue e da mesma forma acontece na paisagem do exterior: Não há sentimento e, por cima, o conceito; o olhar interioriza a norma; por mais singular que seja, nossas percepções estão culturalmente categorizadas e não menos diante da natureza do que diante dos quadros.

A pintura e a literatura carregam sempre a ilusão do instante, trazem toda a existência dentro de si apenas enganosamente congelada, pois o processo é que está congelado, e o processo de criação nunca se encerra em uma obra de arte, ele acontece justamente nesse interrompimento que as obras de arte proporcionam ao mundo, ao tempo. A definição de Obra para Blanchot é diversa à utilizada pelo senso comum, como nos esclarece Daisy Turrer: $a$ obra é um espaço que não se fecha e que escapa ao próprio escritor, que como artista vislumbra apenas seu horizonte (...) A obra torna-se, pois, o movimento que nos encaminha para o ponto puro da inspiração de onde vem e que aparentemente só pode atingir desaparecendo. ${ }^{1}$ Sobre esse desaparecimento, penso na palavra em si ou na cor em si, o nome da cor denominando a cor que já é e só é cor como sensação e que, ao virar palavra, desdobra-se, encontra um nome que é sua ausência em ponto de cor, e que é também uma outra coisa em si. Assim, por exemplo, o poeta Haroldo de Campos² diz em seu poema dedicado à Mira Schendel, que em suas imagens prevalece

1 TURRER. Maurice Blanchot, p. 14.

2 Poema de Haroldo de Campos publicado no catálogo Mira Schendel, relativo à exposição da artista no Museu de Arte Moderna do Rio de Janeiro, em 
uma arte onde a cor pode ser o nome da cor, ou seja, o sentido inenarrável consegue se aproximar da palavra que o cerca.

uma arte de vazios

onde a extrema redundância começa a gerar informação original uma arte de palavras e de quase palavras

onde o signo gráfico veste e desveste vela e desvela

súbitos valores semânticos

uma arte de alfabetos constelados

de letras-abelhas enxameadas ou solitárias

$\mathrm{a}-\mathrm{b}-(\mathrm{li})$-aa

onde o dígito dispersa seus avatares

num transformismo que visa ao ideograma de si mesmo

que força o digital a converter-se em analógico

uma arte de linhas que se precipitam

e se confrontam por mínimos vertiginosos de espaço

sem embargo habitados por distâncias insondáveis

de anos-luz

uma arte onde a cor pode ser o nome da cor

e a figura o comentário da figura

para que entre significante e significado

circule outra vez a surpresa

uma arte-escritura

de cósmica poeira de palavras

uma semiótica arte de ícones índices símbolos

que deixa no branco da página seu rastro numinoso

esta arte de mira schendel

entrar no planetarium onde suas composições

se suspendem desenhos estelares

e ouvir o silêncio como um pássaro de avessos

sobre um ramo de apenas

gorjear seus haicais absolutos

Maria Eduarda Marques em seu texto sobre Schendel, $A$ Estética da Expressividade Minima, aponta que Haroldo em seu poema para a exposição da artista consagra uma dialética, não comentando ou interpretando a obra da artista, afinal o desenho e a poesia partilham da mesma lógica, habitando uma intersecção entre a visualidade e a linguagem.

maio de 1966. In: Mira Schendel: a estética da expressividade mínima, de Maria Eduarda Marques. São Paulo: Cosac e Naif, 2001. 
Esse encontro entre a paisagem e sua palavra, resumidamente passa então pelo seguinte caminho: a imagem da "paisagem" pintada ou desenhada que já era percebida, mas, após ser representada, passa a existir como recorte, como janela, como ponto de vista e posteriormente ou, no máximo concomitantemente, passa a existir como palavra, modificando-se até ser incorporada à realidade, na qual se multiplica; como na enciclopédia, onde existe a própria enciclopédia como termo. Pelo ponto de vista do exterior, essa paisagem imagem pintada e essa paisagem natureza contemplada não são separadas, uma imagem da outra. Ambas são imagens de si mesmas e ambas se permitem.

De forma semelhante, qualquer palavra e ainda mais a palavra Paisagem sobre a paisagem cria um eco, que pressupõe sempre um distanciamento, que se dilui na imensidão do horizonte. Como Eco e Narciso, a palavra e a imagem, em eterna duplicação uma sobre a outra, propõem o infinito, em um encontro impossível (ou um possível desencontro). Esse desencontro é ir de encontro ao erro e à possibilidade; nesse caso, é vista como o ser mais o poder de ser, ou seja, eu só sou porquê de alguma forma posso ser. O impossível, segundo Blanchot, não está aí para fazer capitular o pensamento mas o deixar e anunciar sob uma outra medida que não a do poder. ${ }^{3}$

3 BLANCHOT. A conversa infinita, p. 87. 


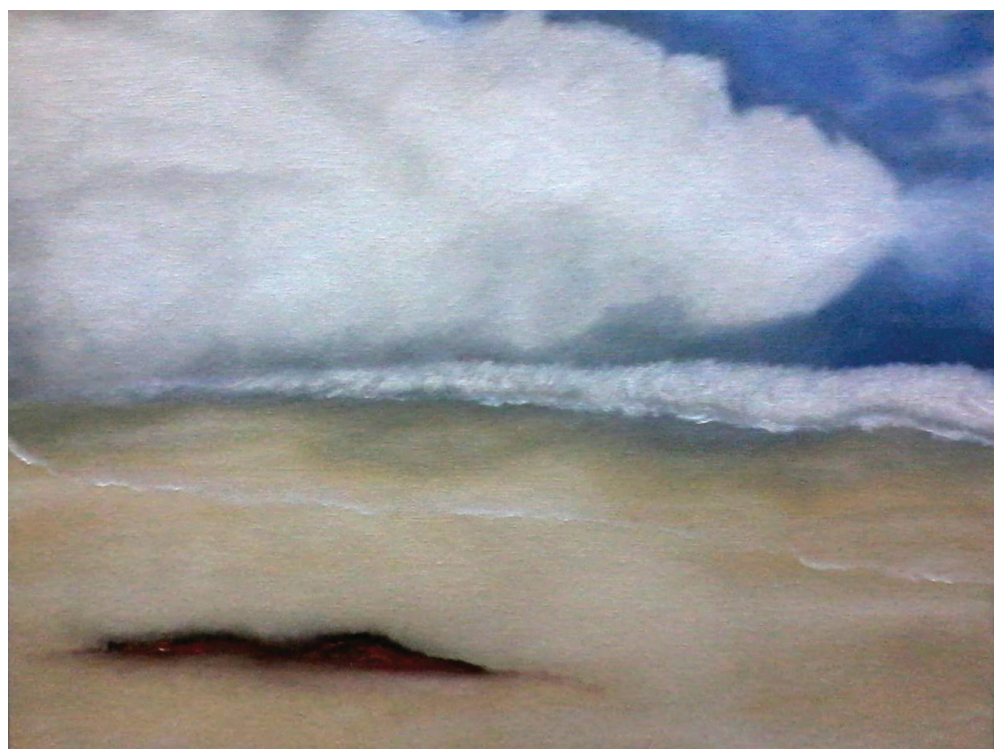

Tadeu Lobato, óleo sobre papel. Fotografia de Alberto Amaral.

A paisagem se explicita enquanto é descrita, se explicita em sua ausência, visto que quanto mais o canário a descreve menos realmente a sabe, quanto mais as palavras tentam dar conta do visível, da descrição daquilo que envolve e forma uma paisagem, mais elas mostram a negação das substâncias do que representam ${ }^{4}$.

$\mathrm{Na}$ paisagem do pensamento aqui proposta, pensa-se a fronteira como um espaço entre, como essa janela que não mais apresenta um recorte externo ou interno, e sim que apresenta os dois ao mesmo tempo, como dois espelhos que se miram, gerando dois infinitos, uma janela que proporciona o fluxo de um espaço em outro. Dessa forma, nos distanciamos da dicotomia dentro-fora

4 BLANCHOT. A parte do fogo, p. 299. 
para uma relação de fluxo, onde surgem as zonas de interferência e de todo o tipo de trocas.

Na escrita de Maurice Blanchot, o infinito é sempre presente, e o espaço "indeterminado" é uma constante, afinal a obra é espaço aberto e indeterminado; ela não é acabada e nem inacabada, ela é. ${ }^{5}$ O que significa dizer que a obra é? Ao citar Valéry, Blanchot aponta que celebrando na obra esse privilégio do infinito, ainda vê nela o lado mais fácil: que a obra seja infinita, isso significa (para ele) que o artista, não sendo capaz de lhe pôr fim, é capaz, no entanto, de fazer dela o lugar fechado de um trabalho sem fim, cujo inacabamento desenvolve o dominio do espirito, exprime esse dominio, exprime-o desenvolvendo-o, sob a forma de poder (BLANCHOT, 1997, p. 12).

Nesse âmbito da Obra, colocada por Blanchot, imaginamos o imaginário, que é o espaço literário mostrado pelo autor. Um espaço eternamente vago, que ambiguamente é, ao mesmo tempo, eternamente gravado pela Paisagem, se pensarmos a paisagem como um pressuposto, uma imanência para que ocorram as imagens que por sua vez a configuram. Por exemplo, partindo da Pintura como farol e do visível como sentido estrito para configuração de tal técnica, Maurice Merleau-Ponty coloca: Nada muda se ele (o pintor) não pinta a partir do motivo: ele pinta, em todo caso, porque viu, porque o mundo, ao menos uma vez, gravou dentro dele as cifras do visivel. (MERLEAU-PONTY, 2004, p. 12).

5 BLANCHOT. O Espaço Literário, p. 12. Entretanto, a obra - a obra de arte, a obra literária - não é acabada nem inacabada: ela é. O que ela nos diz é exclusivamente isso: que é - e nada mais. Fora disso, não é nada. Quem quer fazê-la exprimir algo mais, nada encontra, descobre que ela nada exprime. 


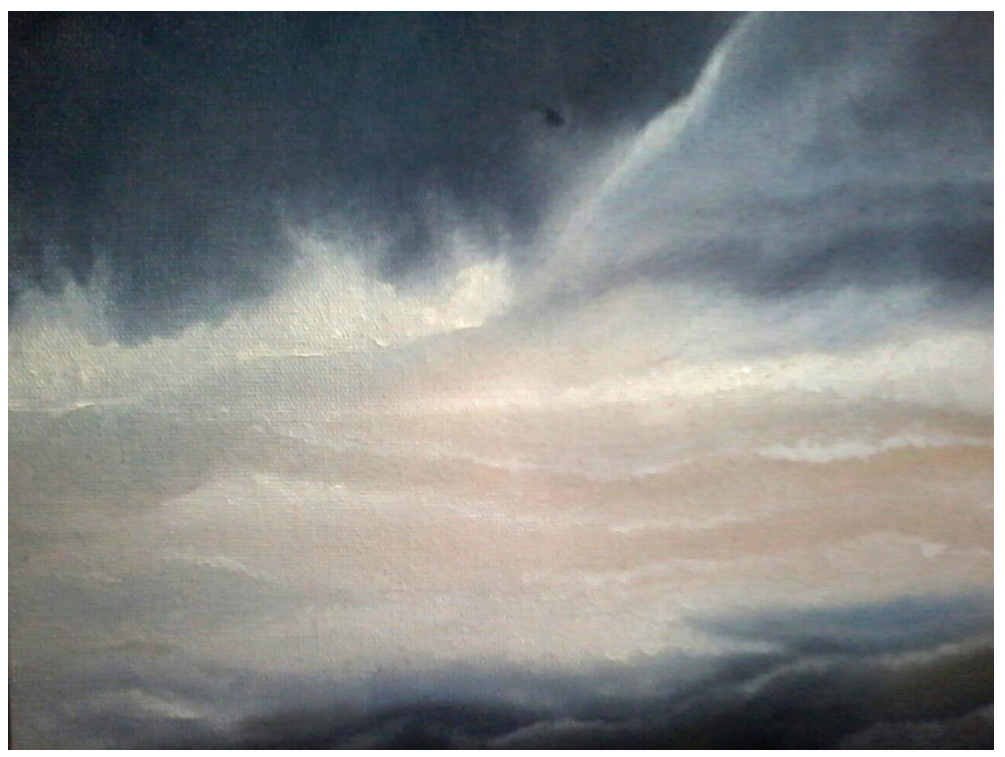

Tadeu Lobato, óleo sobre papel. Fotografia de Alberto Amaral.

Esses espaços, todos eles são coexistentes em outro espaço também vagamente delimitado, o Pensamento. Uma paisagem do pensamento, por exemplo, dentre várias que por este estudo passam, é sugerida por Jaques Derrida, comparando-o com o tímpano. O filósofo cria uma imagem do pensamento em que o tímpano é uma tela estendida, pronta a receber pancadas, a amortecer impressões, a fazer ressoar os tipos, a equilibrar as pressões do dentro e do fora. ${ }^{6}$ A obliquidade do tímpano permite uma maior vibração e a percepção externa das ondas sonoras se torna interna. Essa obliquidade é necessária assim como a obliquidade do pensamento é necessária para que se possa pensar de outra forma, pensar o pensamento.

6 DERRIDA. Timpanizar a filosofia. In: Margens da Filosofia, p. 11. 
Ainda sobre a composição e sobre esses encontros entre as imagens, Blanchot, ao tratar da escrita de Henry James, no capítulo sobre o livro $A$ volta do parafuso, chama de "paradoxo apaixonado do plano"7 a segurança de uma composição determinada de antemão, que, no entanto, possui também a felicidade da criação, que nesse caso, coincide com a pura indeterminação da obra, que a põe à prova, mas sem reduzi-la, sem privá-la de todos os possíveis que ela contém. Esse estado paradoxal apaixonado do plano é uma imagem que exemplifica bem a escolha sempre incerta que é a base de qualquer processo criativo, escolha que paradoxalmente atravessa quem a executa. Essa felicidade da criação é a grande alegria de Farnese, além da falsa sensação de uma determinação definitiva e conclusa.

Criando um paralelo com a noção apresentada de Blanchot, temos também a linha sóbria, outra noção deleuzeana, uma outra imagem do pensamento que também passeia nesse assunto paisagem-velocidade-criação. É a parte que limita para tornar ilimitada a composição. Pode ser a ponta do iceberg ou então sua maioria encoberta, transparente ou escancarada. Muitas vezes o artifício originado por uma dificuldade técnica, por exemplo, da utilização de algum material de desenho, que gera uma busca extremamente forte e traça o trajeto de uma poética, a busca por uma superação de alguma aparente insuficiência técnica ou a extrema paixão por um atrito causado pelo arranhar do lápis dermatográfico no papel.

Todos esses pontos de partida, caminhos e muitos outros são motivos suficientes para se estabelecer pontos de sensação em forma de desenhos, imagens ou palavras, ou, usando o vocabulário de Deleuze, para se estabelecerem linhas de força.

7 BLANCHOT, M. O livro por vir, p. 194. 
Esse horizonte é uma imagem que remete ao comentário dos próprios filósofos acerca da pintura: $O$ quadro não é a delimitação de uma superfície pictórica mas o estabelecimento de uma relação imediata com o exterior. Para os autores, o plano de imanência da filosofia e o plano de composição da arte podem deslizar um no outro, a tal ponto que certas extensões de um sejam ocupadas por entidades do outro. ${ }^{8}$ Esse corte delimitado, determinado por uma velocidade infinita ou espaço vagamente delimitado, como uma pintura, como uma pérola em seu estado pérolareia ${ }^{9}$, como um arco-íris, como qualquer coisa que pode ser atravessada por uma velocidade, por uma potência, desencadeia encontros dos mais diversos, impossíveis e possíveis. Pode ser que desse encontro não surja nada, ou melhor, resulte em uma força que atravessa algum corpo e simplesmente isso, se dissipando, mas pode ser que se transformem em algo, vago e delimitado, paradoxalmente.

Evoco o texto $A$ inelutável cisão do ver, de Georges DidiHuberman, para tratar do assunto da visibilidade mais de perto, dessa distância tão falada entre o que vemos e aquilo que é olhado e que, no entanto, nos olha, o que inclui fortemente o modelo e o pintor. Segundo o autor, acompanhando a escrita de Joyce, o ato de ver só se manifesta ao se abrir em dois; fechemos os olhos para ver. O olhar toca: devemos fechar os olhos para ver quando o ato de ver nos remete, nos abre um vazio que nos olha, nos concerne e, em certo sentido, nos constitui. Vemos a imagem que se torna inelutável quando uma perda a suporta.

Blanchot trata da imagem em seu texto "As duas versões do imaginário" e acredito existir uma ponte entre suas colocações e

8 DELEUZE, GUATTARI, O que é a filosofia?, p. 89.

9 WEISSMANN, 2008. 
o que Didi-Huberman fala, da perda que suporta a imagem que vemos. Ao começar perguntando: o que é a imagem? Diz que ela encontra sua condição no nada, no entanto desaparecendo nele, como a palavra poética que só aparece em seu desaparecimento. A imagem é um limite perto do indefinido e essa é sua felicidade, segundo Blanchot. Para o autor, uma das funções da imagem é a de apaziguar, dar forma, humanizando o informe, falando-nos intimamente de nós, mais precisamente sobre o rosto, que é foco no presente capítulo. Ao estarmos diante de um, só o notamos como rosto se esquecemos que na verdade é um rosto, porque pensamos a imagem como a continuação do objeto, a imagem do objeto não é o objeto em si, possui sua própria realidade. Blanchot diz: a coisa estava aí, que nós apreenderíamos no movimento vivo de uma ação compreensiva e, tornada imagem, ei-la instantaneamente convertida no inapreensível, inatual, impassível, não a mesma coisa distanciada, mas essa coisa como distanciamento, a coisa presente em sua ausência (...). Ao comparar a estranheza cadavérica com a estranheza da imagem, Didi-Huberman se aproxima de Blanchot e, acredito eu, chega a um importante ponto que tanto sempre aproximou o olhar humano sobre os retratos. Essa imagem como ausência presente é comparável à presença do cadáver, como imagem da morte, daquele que olhamos e que não nos olha mais. Talvez a única imagem que não nos olhe seja a do cadáver, visto que ele começa a assemelhar-se a si mesmo, e resta só a sua própria imagem como despojo, não mais dupla, uma presença ausente.

A experiência da pintura nos revela que ela só é possível na sua impossibilidade, como a morte, que nasce quando alguém morre. Ao tratar dos retratos, da cabeça por excelência e o rosto que ela suporta, temos que nos lembrar do que nos diz James Lord, em seu $U m$ retrato de Giacometti, que quanto mais se trabalha em uma 
pintura, mais é impossivel terminá-la. A partir da mesma fonte, James Lord compreende que para que o artista, Giacometti, fosse capaz de ver intensamente e como que pela primeira vez o que estava diante dele, tinha que duvidar a todo momento de sua habilidade e pôr em questão não apenas o que estava fazendo, como também tudo que já tinha feito.

Para concluirmos verificamos que não há literatura e pintura sem a paisagem e não há paisagem na literatura e na pintura sem as possíveis abordagens de luz, sem a iluminação que gera a escolha das cores, a escolha das personagens, das texturas, quartos, palavras, e principalmente, sem o esclarecimento que rege invisivelmente todos os símbolos, rostos, rastros e sonhos que formam o imaginário. Esse trio, literatura, pintura e paisagem, que não se desassocia da claridade está também imerso na memória.

A memória, colocada junto à paisagem por vários teóricos, como na introdução do livro $A$ invenção da paisagem, de Anne Cauquelin, ou no livro Paisagem e memória, de Simon Schamma, é um assunto indissociável de nossa percepção da mesma. Não apenas por sempre nos lembrarmos das paisagens de nossa infância, das sensações que formam essas paisagens, criando sempre a ilusão de eternidade, mas porque nossa duração não é um instante que substitui outro instante: nesse caso, haveria sempre apenas presente, não haveria prolongamento do passado no atual, não haveria evolução, não haveria duração concreta. A duração é o progresso contínuo do passado que rói o porvir e incha à medida que avança. Coloco a memória junto à claridade, porque é o tecido luminoso que molda as possíveis abordagens de timbres, que formam na literatura e na pintura suas paisagens como nos diz Bergson: 
Não temos o que fazer com a lembrança das coisas enquanto temos as próprias coisas. A consciência descarta essa lembrança como inútil e a reflexão teórica a considera inexistente. Assim nasce a ilusão de que a lembrança sucede à percepção (BERGSON, 1999, p. 43).

Querer guardar a fotografia de alguém já pressupõe o seu esquecimento, já traz uma perspectiva de um futuro próximo. A duração, segundo Bergson, não é o tempo que uma coisa dura, sua durabilidade, e sim a invenção; como a metamorfose é a criação de formas, elaboração contínua do absolutamente novo: como, por sua vez, também é o pensamento embebido de memórias.

A questão da criação, e aqui mais particularmente a da pintura, aborda diretamente o conceito de Bergson. Na pintura, seu movimento é eterno e incessante, um nascimento continuado, por sua extensão de uma imagem à outra e por sua capacidade de criar a ilusão do instante, do fixo, do imutável. Não se trata apenas de camadas sobre camadas, advindas de um processo de construção de veladuras, esse processo ilude uma profusão de planos, linhas, símbolos, cores, linhas de força que coexistem (pacificamente ou não) em todas e de todas as direções.

Para Blanchot, Mallarmé dotou o homem de uma experiência nova: o espaço como aproximação de um outro espaço, origem criadora e aventura do movimento poético; vazio movente, lugar onde a tarefa criadora começa, em Paisagens moventes e no livro por vir traz essa duração de que fala Bergson sobre a memória, afinal a obra é a espera pela obra. Blanchot: Nesse espaço - o próprio espaço do livro - jamais o instante sucede o instante, segundo o desenrolar horizontal de um devir irreversivel. Bergson: nossa duração não é um instante que substitui outro instante: nesse caso, haveria sempre apenas presente, não haveria prolongamento do passado no atual, não haveria 
evolução, não haveria duração concreta. A duração éo progresso continuo do passado que rói o porvir e incha à medida que avança.

\section{Referências}

BERGSON, Henri. Matéria e memória. Ensaio sobre a relação do corpo com o espirito. São Paulo: Martins Fontes, 1999.

BERGSON, Henri. Memória e vida: textos escolhidos por Gilles Deleuze. São Paulo: Martins Fontes, 2006.

BLANCHOT, Maurice. O espaço literário. Rio de Janeiro: Rocco, 1987.

BLANCHOT, Maurice. A conversa infinita - 1: a palavra plural (palavra escrita). São Paulo: Escuta, 2001.

BLANCHOT, Maurice. A parte do fogo. Rio de Janeiro: Rocco, 1997.

CAUQUILlAN, Anne. A invenção da paisagem. São Paulo: Martins, 2007.

DIDI-HUBERMAN, Georges. O que vemos, o que nos olha. Trad. Paulo Neves. São Paulo: Ed. 34, 1998.

CASTELLO BRANCO, Lucia; BARBOSA, Márcio Venício; SILVA, Sérgio Antônio. Maurice Blanchot. São Paulo: Annablume, 2004.

DEBRAY, Regis. Vida e morte da imagem: uma história do olhar no ocidente. Petrópolis, RJ: Vozes, 1994.

DELEUZE, Gilles; GUATTARI, Félix. O que é a filosofia? Trad. Bento Prado Jr. e Alberto Alonso Muñoz. Rio de Janeiro: Ed. 34, 1992.

DERRIDA, Jacques. Margens da Filosofia, trad. Joaquim Torres Costa e António M. Magalhães, Lisboa, RÉS-Editora, 1972.

FREUD, S. "Vorlesungen zur Einführung in die Psychoanalyse". In: Gesammelte Werke. Londres: Imago, vol. XI, 1944.

LACAN, Jacques. L'insu que sait de l'une-bérue s'aile à mourre (Seminário 1976-1977). Inédito. 8 mars 1977.

LORD, James. Um retrato de Giacometti. São Paulo: Iluminuras, 1998. 
MALLARMÉ, S. "Richard Wagner. Rêverie d'un Poète Français". In: Écrits sur L'Art. Paris: Flammarion, 1998.

SHAMMAN, Simon. Paisagem e memória. São Paulo: Companhia das Letras, 1996.

RICOUER, Paul. A memória, a história, o esquecimento. São Paulo: Ed. da Unicamp, 2007.

MERLEAU-PONTY, Maurice. O olho e o espirito. São Paulo: Ed. Cosac e Naif, 2004.

WEISSMANN, Anais Lobo. Estórias de amor para crianças. Belo Horizonte: Imprensa Oficial, 1972.

Alberto Amaral é graduado em Geografia pela UFPA; especialização em Filosofia Contemporânea (PUC Rio) e em Saúde Mental e Direitos Humanos (UFPA/ FHCGV); mestre em Teoria Psicanalítica pela UFRJ. Curador e crítico de arte independente, dedica seus estudos no campo da Filosofia da diferença francesa e sua relação com a Psicanálise. Pesquisador dos Grupos Arte, Corpo e Conhecimento (UFPA/CNPq) e Pensamento Blanchotianos e de Pensamento do Fora (UnB/CNPq). Organizador e idealizador do Colóquio Blanchot: literatura, amizade, uma vida - Dez anos da morte de Maurice Blanchot (2013); e do Colóquio: $\mathrm{O}$ que pode o corpo: 30 anos de morte de Michel Foucault (2014). Desenvolve pesquisas em torno da escrita e do pensamento do Fora e do Outro em um intenso diálogo entre a filosofia e as obras de artes (Literatura, fotografia e outras produções artísticas). Tem publicações em âmbito nacional e internacional. E-mail: albertoamaral@gmail.com 